\title{
USING OF CoCr ALLOYS IN BIOMEDICAL APPLICATIONS ( REVIEW)
}

\author{
Haydar H.J. Jamal Al Deen \\ jaberjd@gmail.com
}

Faculty of Materials Engineering, University of Babylon-Iraq.

\begin{abstract}
Metals are used extensively in biomedical applications due to their mechanical strength, corrosion resistance, and biocompatibility. There are many types of metals and alloys used in this application ( stainless steel, $\mathrm{Ti}$ and $\mathrm{Ti}$ alloys, $\mathrm{CoCr}$, dental amalgam, etc). This review focus on $\mathrm{CoCr}$ alloys which have excellent corrosion resistance and mechanical properties which make them the best choice for many types of surgical implants. There are many alloying elements used to improve the properties of $\mathrm{CoCr}$ alloy such as ( $\mathrm{Zr}$, In, Ta, etc ) has been reviewed.
\end{abstract}

Keywords: Biometals, CoCr alloys, surgical implants, biomaterials, biocompatibility, applications.

$$
\begin{aligned}
& \text { استخدام سبائك التطبيقات الطبية ( مراجعة ) } \\
& \text { د. حيدر حسن جابر جمال الدين }
\end{aligned}
$$

تستخدم المعادن على نحو واسع في التطبيقات الطبية بسبب مقاومتها الميكانيكية ومقاومتها للتآكل وتو افقيتها الحياتية.

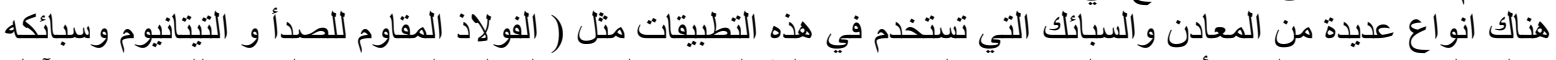

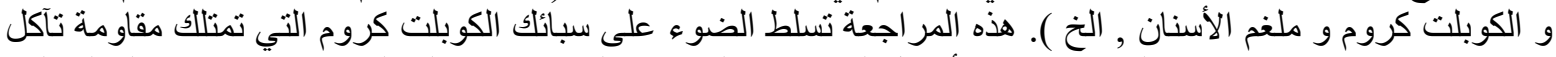

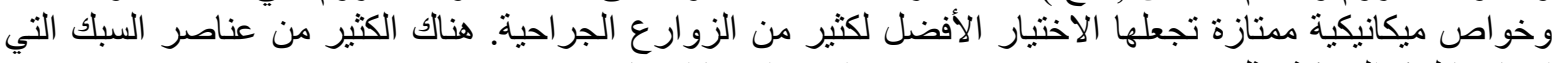

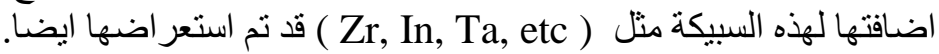




\section{INTRODUCTION}

Metals are considered one of the biomedical materials due to their high mechanical properties. and sufficient biocompatibility. Metals have high strength and resistance to fracture, that necessary for the biomedical load bearing applications. From the available metallic materials, some of them are biocompatible, which are not exhibit toxic reactions in the body, such as cobalt alloys, stainless steels, titanium alloys and noble metals. The corrosion resistance of Co based alloys in vivo better than stainless steels. Although the cobalt alloys are heavy, they have high wear resistance (Donglu Shi,2006). These materials are named as cobalt-chromium alloys. Basically, there are two types: cast CoCrMo alloy and wrought CoNiCrMo alloy. For many years, the first one, used in artificial joints and dentistry, and the second used in making the stems of prostheses for heavily loaded joints (knee and hip) (Joon Park,2007).

\section{BINERY PHASE DIAGRAM OF CoCr ALLOY}

Cobalt faces an allotropic transformation from $\gamma$-phase (high temperature, 690K, fcc structure) to $\varepsilon$-phase (low- temperature hcp structure). This transformation. is (shear dominant) with. thermal hysteresis; thus, it considers as martensitic transformation. The transformation. temperature can be controlled by alloying elements addition. The $\mathrm{Co}-\mathrm{Cr}$ alloys which contain chromium more than. $20 \mathrm{wt} \%$ have high corrosion resistance because of passivation layer formation which consists mainly of chromium oxide. The binary phase. diagram of $\mathrm{Co}-\mathrm{Cr}$ alloy is shown in Figure(1). The chromium addition rises the transformation temperature of the alloy. The transformation temperatures of $\mathrm{Co}-\mathrm{Cr}$ alloy with $20 \mathrm{wt} \% \mathrm{Cr}$ and $30 \mathrm{wt} \% \mathrm{Cr}$ alloys are $(1,100$ and 1,200 K) respectively [Mitsuo,2015].

\section{CHEMICAL COMPOSITION}

The CoCr alloys for biomedical applications are come from $\mathrm{Co}-\mathrm{Cr}$ or $\mathrm{Co}-\mathrm{Ni}-\mathrm{Cr}$ system which poses high corrosion resistance and strength. The commonly used alloys for biomedical applications are:

1. Cast or P/M Co-Cr-Mo (F75 or Stellite 21).

2. Wrought $\mathrm{Co}-\mathrm{Cr}-\mathrm{W}-\mathrm{Ni}$ (F90 or Stellite 25).

3. Co -Ni -Cr-Mo - Ti (F562 or MP35N).

All the $\mathrm{Co}-\mathrm{Cr}$ alloys of medical applications are of carbon $(\mathrm{C}=0.25 \mathrm{wt} \%)$, the chemical compositions are listed in Table 1 Donglu Shi (2006).

Both $\mathrm{Co}$ and $\mathrm{Cr}$ form solid solutions $(\varepsilon)$ in the alloys according to phase diagram shown in Figure(1). Cr improves corrosion resistance as well as solid solution strengthening. Molybdenum addition refine the grains and solid solution strengthening. $\mathrm{W}$ and $\mathrm{Ni}$ (in F90) are added to enhance fabrication properties and machinability. The implants made of F75 (Stellite21) by using investment casting. F562 (multiphase alloy) with high percentage of $\mathrm{Ni}$, that stabilizes solid solution with fcc structure $(\alpha)$, by this composition, strengthening can be done phase transformation from fcc $\alpha$ phase to hep $\varepsilon$ phase during cold working and can be strengthen by precipitation hardening ( $\mathrm{Co}_{3} \mathrm{Mo}$ ) through subsequent aging Donglu Shi (2006).

Many researchers investigate the effect of addition of some elements such as (Ge, Y, Te and In) on mechanical and electrochemical properties of $\mathrm{Co}-\mathrm{Cr}$ alloy, where they achieved interesting results made the alloy of excellent corrosion resistance and mechanical properties Jamal Al-Deen (2016), Haleem (2016), Jamal Al-Deen (2018).

\section{MICROSTRUCTURE}


Microstructure of Co alloys depend on processing conditions. Figure(2a) shows the typical casting microstructure of the cast F75 alloy (Co rich) consisting of $\varepsilon$ - phase (light background) with interdendritic carbides (dark areas). The solidification process leads to grain growth which is unfavorable due to low their strength. Wrought alloy produced by hot forging, by which the carbides formation and grain refinement in F75 alloy is achieved that improve alloy strength, the microstructure is shown in Figure(2b). The F562 consists of fcc structure fine grains and hcp plates as shown in Figure(3). Such microstructure indicates high strength of this multiphase alloys resulting from the solid solution strengthening, the grain and/ or phase. boundary strengthening and the. precipitation strengthening. after cold working and aging Donglu Shi (2006), M. Walter (2006).

\section{MECHANICAL PROPERTIES}

Generally, Co-Cr alloy have higher Young s modulus and strength than stainless steel, though their ductility is slightly poorer. Co-Cr alloys have better wear resistance than other alloys. Wear resistance of metallic materials depends on hardness, which increases with yield and tensile strength. The high wear resistance of $\mathrm{Co}-\mathrm{Cr}$ alloys can be demonstrated by their strengths as shown in Table 2. The mechanical properties of $\mathrm{Co}-\mathrm{Cr}$ alloys are depending on processing condition. F799, which is the hot forged version of F75, has much higher yield and tensile strength with enhanced ductility than its cast counterpart. The cold-working effectively strengthens F90 as indicated in Table 2. The cold working plus aging is more effective than cold working alone to strengthen the multiphase alloy F562 as shown in Figure(4) Donglu Shi (2006), Odahara,T (2008), Nasab (2010).

\section{CORROSION RESISTANCE}

The passive layer on the surface of $\mathrm{Co}-\mathrm{Cr}$ alloys gives excellent corrosion resistance, that prevents further corrosion under in vivo environments. Cobalt and chromium form complex oxides whereas molybdenum forms low percentage of oxides like hydroxyl groups (2.5nm thickness)( Smith (1991), Hanawa, 2000). The dissolution and reprecipitation of passive layers in vivo are continuous. Co was dissolved. from the passive layer. during immersion. in Hanks' solution and in-service environment. Therefore, the main components of the passive layer are $\mathrm{Cr}$ oxide and little amount. of Mo oxide. Hodgson et al. Hodgson (2004) studied the passivation layer of a Co-28Cr-Mo alloy in vivo using X-ray. photoelectron spectroscopy. (XPS). They concluded that $\mathrm{Co}$ was the main element dissolving from the alloy and the main components of the passive layer was $\mathrm{Cr}$ (III) oxide and a smaller amount of $\mathrm{Cr}$ (III) hydroxide.

The anodic polarization of as-cast and heat-treated Co-28Cr-6Mo-0.24C alloys in Hanks' solution are shown in Figure (5). The accomplished heat treatment (12 hrs) was at 1,523 and $1,623 \mathrm{~K}$. The alloy heat-treated at $1,523 \mathrm{~K}$ had no precipitates, while, in the as-cast alloy and the alloy heat-treated, the main precipitates at $1,623 \mathrm{~K}$ were of $\mathrm{M}_{23} \mathrm{X}_{6}$ type and $\pi$-phase, respectively. The precipitates have low effect on the corrosion resistance (Mitsuo (2015), H. Hermawan (2011), Jacobs (1998), H. Hermawan,2010).

\section{BIOCOMPATIBILITY}

Biocompatibility defined as. the ability of certain material to function with an. appropriate host. response in a specific situation. Biocompatibility is a measurement of the property which should be evaluated primarily. In biomedical applications, when choosing a material, there are 
several requirements needed to meet specification for certain application such as corrosion resistance, biotolerance. mechanical and tribological properties (Hodgson (2004), Northwestern (2007), Süry (1978), Ouerd 2008).

\section{APPLICATIONS}

Table 3 shows the Co-Cr alloys applications. Generally, the applications of these alloys are as follow (stem, ball, and cup of artificial hip joints, knee joints) (Donglu Shi (2006), H. Hermawan, 2010).

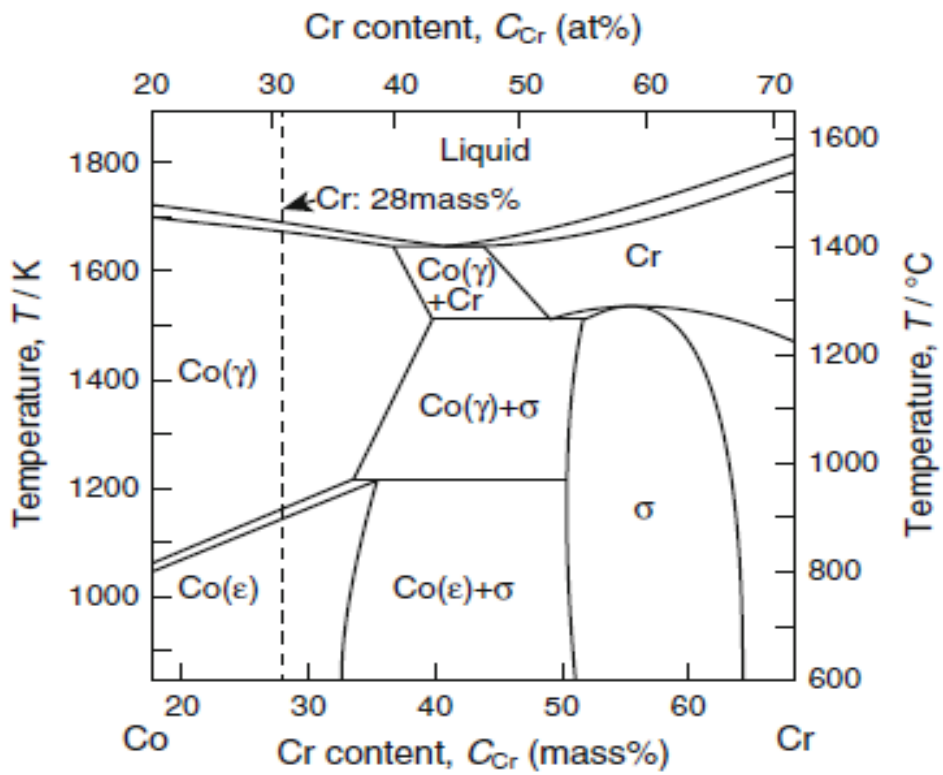

Fig.1. Binary phase diagram of the Co-Cr system (Mitsuo ,2015)

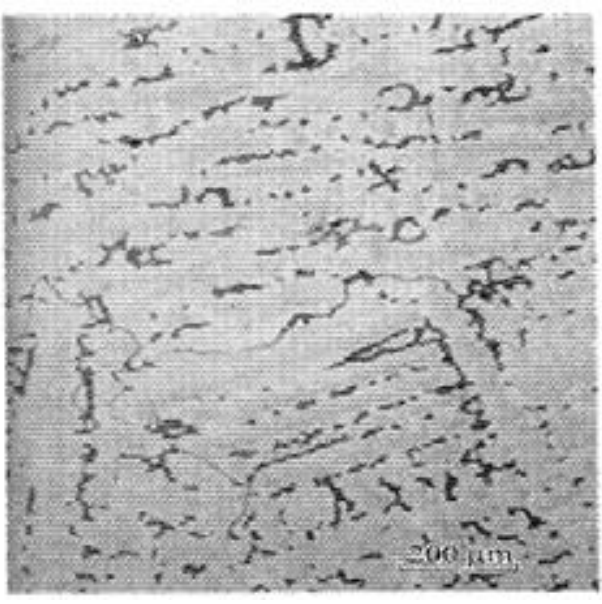

(a)

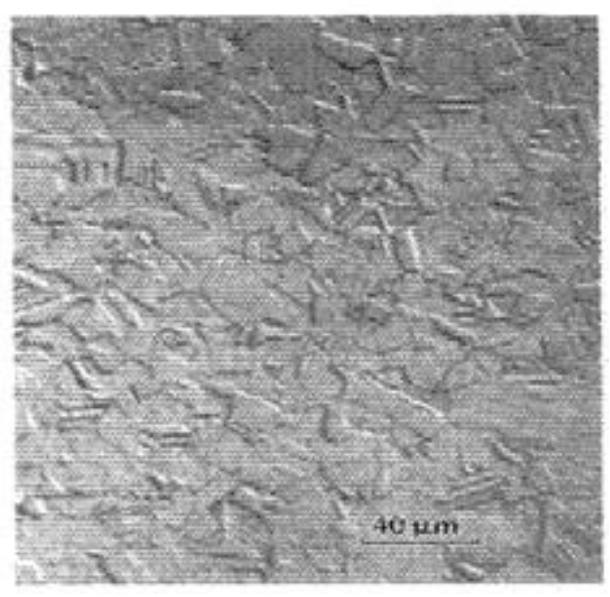

(b)

Fig.2. Microstructure of cobalt-based alloy F75. (a) micrograph of casting microstructure; (b) micrograph of wrought microstructure by interference contrast (Donglu Shi 2006). 


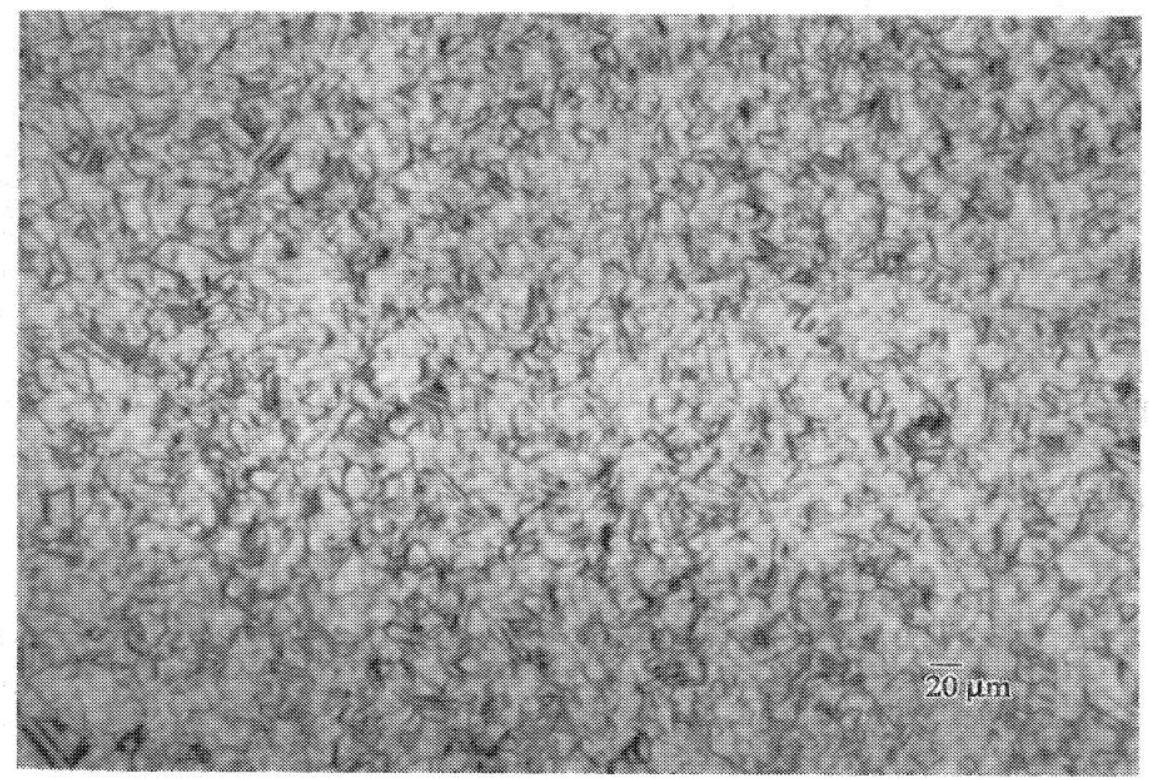

Fig.3. Microstructure of cobalt-based alloy F562. The equiaxed FCC grains mix with the dark HCP platelets (Donglu Shi 2006).

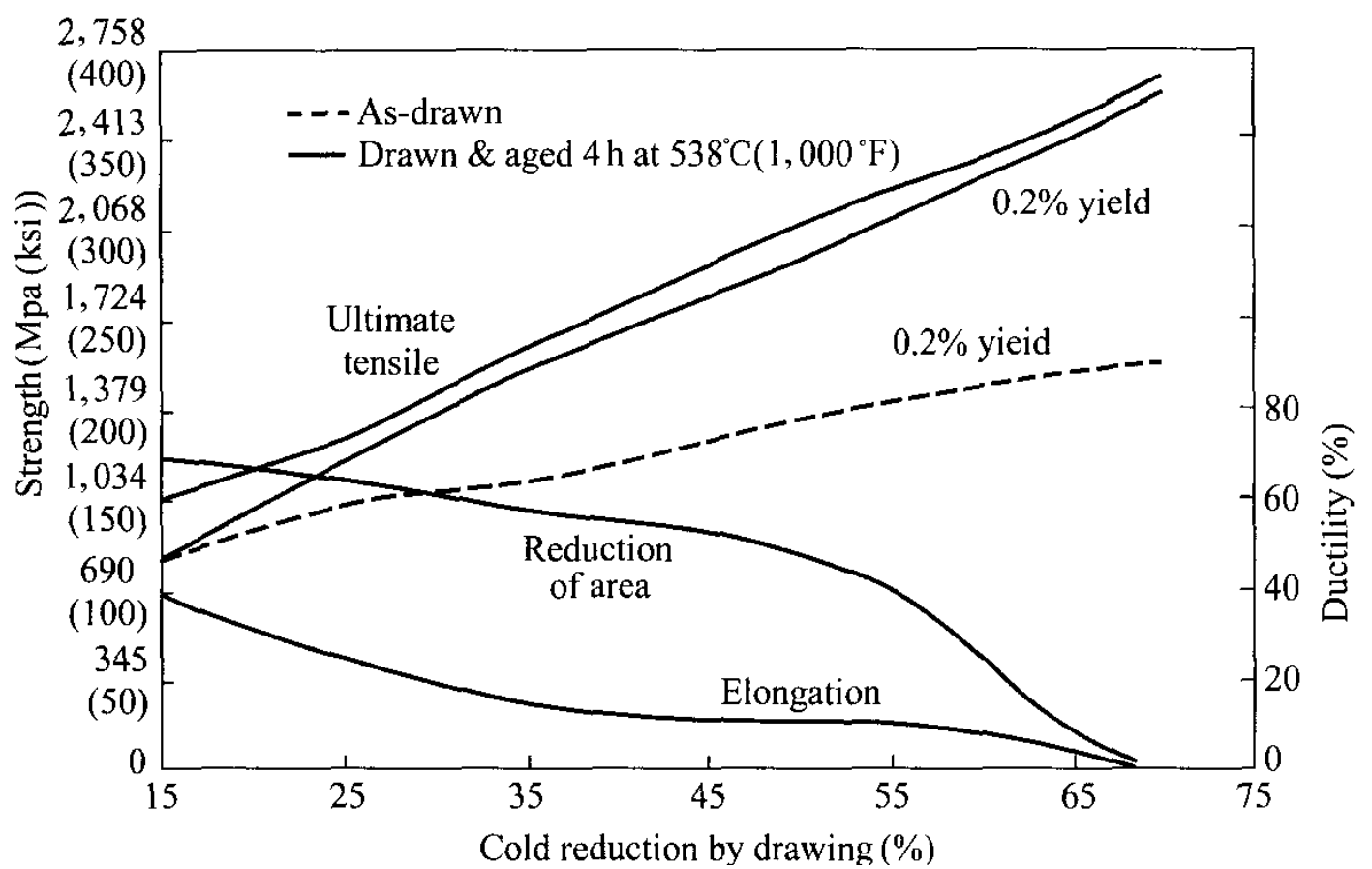

Fig. 4. Mechanical properties of Co-Ni-Cr-Mo F562 as a function of amount of cold work (Donglu Shi ,2006). 


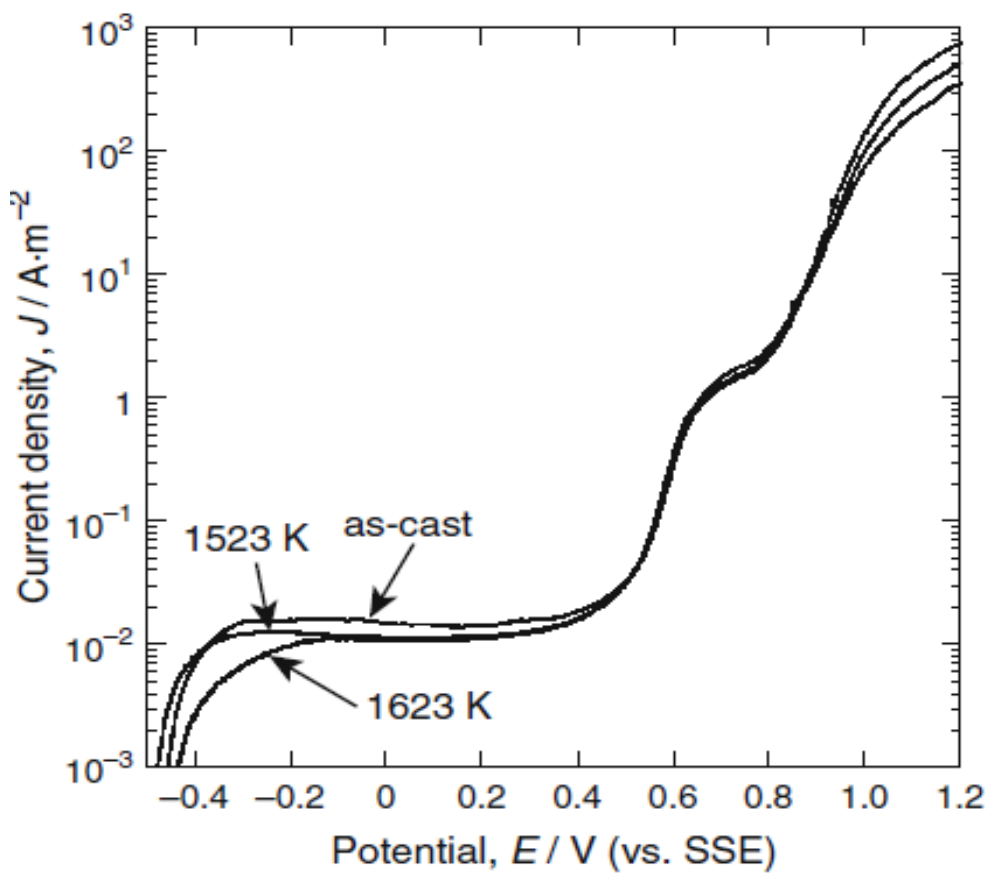

Fig.5. Anodic polarization curves in Hanks' solution for as-cast Co-28Cr- $6 \mathrm{Mo}-0.24 \mathrm{C}$ alloy and for alloys heat treated at 1,523 and 1,623 K Mitsuo (2015).

Table1. Compositions of Co-Cr alloys for biomedical implants (wt\%) (Donglu Shi 2006).

\begin{tabular}{||c|c|l|l|l|l|l|l|l|l||}
\hline Alloys & $\begin{array}{c}\text { ASTM } \\
\text { Designation }\end{array}$ & Co & Cr & Mo & W & Ni & Fe & Si & Mn \\
\hline \hline $\begin{array}{c}\text { Cast or P/M } \\
\text { Co-Cr-Mo }\end{array}$ & F75 & Bal & $27-30$ & $5-7$ & $\cdots$ & 2.75 & 0.75 & 1.0 & 1 \\
\hline $\begin{array}{c}\text { Wrought } \\
\text { Co-Cr-W-Ni }\end{array}$ & F90 & Bal & $19-21$ & ----- & $14-16$ & $\begin{array}{c}3 \\
(\max )\end{array}$ & $\begin{array}{c}3 \\
(\max )\end{array}$ & 0.4 & $1-2$ \\
\hline $\begin{array}{c}\text { Wrought } \\
\text { Co-Ni-Cr-Mo }\end{array}$ & F562 & Bal & $19-21$ & $9-10.5$ & $\cdots$ & $\begin{array}{c}1 \\
(\max )\end{array}$ & $\begin{array}{c}1 \\
(\max )\end{array}$ & $\begin{array}{c}0.15 \\
(\max )\end{array}$ & $\begin{array}{c}0.15 \\
(\max )\end{array}$ \\
\hline
\end{tabular}

Table2. Mechanical properties of cobalt-based for biomedical implants (Donglu Shi ,2006).

\begin{tabular}{|c|c|c|c|c|c|c|}
\hline Alloys & $\begin{array}{l}\text { Treatment } \\
\text { condition }\end{array}$ & $\begin{array}{c}\text { ASTM } \\
\text { Designation }\end{array}$ & $\begin{array}{c}\begin{array}{c}\text { Young } \\
\text { modulus } \\
(\mathrm{GPa})\end{array} \\
\end{array}$ & $\begin{array}{c}\text { Yield } \\
\text { strength } \\
\text { (MPa) } \\
\end{array}$ & $\begin{array}{l}\begin{array}{l}\text { Tensile } \\
\text { strength } \\
\text { (MPa) }\end{array} \\
\end{array}$ & $\begin{array}{c}\text { Ductility } \\
\text { (\% elongation) }\end{array}$ \\
\hline Co-Cr-Mo & cast & F75 & 248 & 4450 & 655 & 8 \\
\hline Co-Cr-Mo & Wrought & F799 & $\cdots \cdots$ & 827 & 1172 & 12 \\
\hline $\mathrm{Co}-\mathrm{Cr}-\mathrm{W}-\mathrm{Ni}$ & Wrought & F90 & 242 & 379 & 896 & $\ldots$ \\
\hline $\mathrm{Co}-\mathrm{Cr}-\mathrm{W}-\mathrm{Ni}$ & $\begin{array}{c}\text { Wrought } \\
44 \% \text { cold } \\
\text { worked }\end{array}$ & F90 & $\ldots \ldots$ & 1,606 & 1896 & $\ldots$ \\
\hline Co-Ni-Cr-Mo & Annealed & F562 & 228 & $241-448$ & $\begin{array}{l}793- \\
1000\end{array}$ & 50 \\
\hline Co-Ni-Cr-Mo & $\begin{array}{l}\text { cold worked } \\
\text { and aged }\end{array}$ & F562 & $\ldots \ldots \ldots$ & 1,586 & 1793 & 8 \\
\hline
\end{tabular}

Table 3. Applications of Co-Cr alloys Donglu Shi (2006). 


\begin{tabular}{|c|c|c|c|}
\hline ASTM & Alloys (mass\%) & Trade name & Application \\
\hline F 75-12 & \multirow[t]{3}{*}{ Co-28Cr-6Mo } & $\begin{array}{l}\text { Vitallium (Howmedica, } \\
\text { Inc) } \\
\text { Haynes-Stellite } 21 \\
\text { (HS21) (Cabot Corp.) } \\
\text { Protasul-2 (Sulzer AG) } \\
\text { Zimaloy (Zimmer Inc.) }\end{array}$ & $\begin{array}{l}\text { Stem, ball, and cup of } \\
\text { artificial joints. } \\
\text { Fixation screws. } \\
\text { Bone plates }\end{array}$ \\
\hline F 799-11 & & \multirow{2}{*}{$\begin{array}{l}\text { BioDur CCM Plus } \\
\text { Alloy } \\
\text { (Carpenter Technology } \\
\text { Corp.) }\end{array}$} & \multirow{2}{*}{$\begin{array}{l}\text { Joint replacements } \\
\text { (hip, knee, shoulder) } \\
\text { Fixation devices }\end{array}$} \\
\hline F 1537-11 & & & \\
\hline F 90-09 & \multirow[t]{2}{*}{ Co-20Cr-15W- $10 \mathrm{Ni}$} & \multirow{2}{*}{$\begin{array}{l}\text { Haynes-Stellite } 25 \\
\text { (HS25) (Cabot Corp.). } \\
\text { L-605 (Carpenter } \\
\text { Technology } \\
\text { Corp.) }\end{array}$} & \multirow{2}{*}{$\begin{array}{l}\text { Fixation wires. } \\
\text { Vascular stents } \\
\text { Heart valves }\end{array}$} \\
\hline F 1091-12 & & & \\
\hline F 562-13 & \multirow[t]{3}{*}{ Co-35Ni-20Cr-10Mo } & \multirow{3}{*}{$\begin{array}{l}\text { MP35N (SPS } \\
\text { Technologies, Inc.) } \\
\text { Biophase (Richards } \\
\text { Medical Co.) } \\
\begin{array}{l}\text { Protasul-10 } \\
\text { AG) }\end{array}\end{array}$} & \multirow{3}{*}{$\begin{array}{l}\text { Lead conductor wires } \\
\text { Springs } \\
\text { Stylets } \\
\text { Catheters } \\
\text { Orthopedic cables } \\
\text { Cardiovascular stents }\end{array}$} \\
\hline F 688-10 & & & \\
\hline F 961-08 & & & \\
\hline F 1058-08 & $40 \mathrm{Co}-20 \mathrm{Cr}-16 \mathrm{Fe}-15 \mathrm{Ni}-7 \mathrm{Mo}$ & $\begin{array}{l}\text { Elgiloy (Elgiloy Ltd.) } \\
\text { Phynox (ArcelorMittal } \\
\text { Stainless \& Nickel } \\
\text { Alloys) } \\
\text { Conichrome (Carpenter } \\
\text { Technology Corp.) }\end{array}$ & $\begin{array}{l}\text { Arch wires } \\
\text { Springs } \\
\text { Lead conductor wires } \\
\text { Surgical clips } \\
\text { Balloon-expandable } \\
\text { stents (annealed) } \\
\text { Self-expanding stents } \\
\text { (aged) }\end{array}$ \\
\hline
\end{tabular}




\section{REFERENCES}

A.H. Haleem, H.H.J. Jamal Al-Deen and A.H. Khilfe, Studying the Properties of CoCrMo Alloys (F75) Doped Ge Using (Powder Metalluregy) Technique, Journal of Babylon University, Vol.24, No.3, 2016.

Donglu Shi (Introduction to Biomaterials), Tsinghua University Press, Tsinghua University, China, 2006.

DC Smith, RM Pilliar, JB Metson, NS McIntyre, Dental implant materials. II. Preparative procedures and surface spectroscopic studies, J Biomed Mater Res,Vol.25,pp. 1069-1084,1991.

H.H.J. Jamal Al-Deen, A.H. Haleem and A.H. Khilfe, Studying the properties of CoCrMo (F75) doped Ge using (P-M) technique, International Journal of Metallurgical, Materials and Chemical Engineering, Vol. 1, No. 1, pp.11-20, Dec. Jan 2016.

H.H.J. Jamal Al-Deen and E.A.R. Hassani, Effect Of In Addition On The Properties Of CoCrMo (F75) Alloy Using P/M Technique, Journal of Engineering and Applied Sciences, Vol.13,spcial Issue 12,pp.9497-9502, 2018.

H. Hermawan, D. Dubé and D. Mantovani."Developments in metallic biodegradable stents". Acta Biomaterial, 2010.

H. Hermawan, D. Ramdan and J. R. P. Djuansjah, "Metals for Biomedical Applications". Faculty of Biomedical Engineering and Health Science, University Teknologi Malaysia. Chapter 17, 2011.

Hodgson AWE, Kurz S, Virtanen S, Fervel V, Olsson C-OA, Mischler S ,Passive and transpassive behaviour of $\mathrm{CoCrMo}$ in simulated biological solutions, Electrochimica Acta,Vol.49, pp,2167-2178, 2004.

J.J. Jacobs, J.L. Gilbert and R. M. Urban, "Current Concept Review-Corrosion of Metal Orthopaedic Implants", Journal of Bone \& Joint Surgery, Vol.80, pp. 268-282, 1998.

Joon Park and R.S. Lakes (Biomaterials An Introduction), springer,2007

Mitsuo Niinomi, Takayuki Narushima and Masaaki Nakai, Advances in Metallic Biomaterials, New York, Springer,2015.

M. Walter. "Benefits of P/M Processed Cobalt-Based Alloy for Orthopedic Medical Implants", Carpenter Technology Corp., Wyomissing, PA, USA, 2006.

Northwestern,"Biomaterials for Orthopedic Implants and Bone Regeneration". P:208, 2007.

Nasab, M. B., Hassan, M. R., and Sahari, B. B. 'Metallic biomaterials of knee and hip-A review', Trends Biomater. Artif. Organs, Vol. 24, pp. 69-82, 2010. 
Odahara,T. Matsumoto,H. and Chiba,A.,"Mechanical Properties of Biomedical Co-33Cr-5Mo$0.3 \mathrm{~N}$ Alloy at Elevated Temperatures" Institute for Materials Research, Tohoku University, Sendai 980-8577, 2008.

Ouerd, A., Alemany-Dumont, C., Normand, B., and Szunerits, S. reactivity of CoCrMo alloy in physiological medium: Electrochemical characterization of the metal/protein interface, Electrochimica Acta, Vol. 53, pp. 4461-4469, 2008.

Süry, P., and Semlitsch, M. 'Corrosion behavior of cast and forged cobalt-based alloys for doublealloy joint endoprostheses', Journal of Biomedical Materials Research Part A, Vol. 12, pp. 723741, 1978.

T Hanawa, S Hiromoto, K Asami, Characterization of the surface oxide fi $\mathrm{lm}$ of a $\mathrm{Co}-\mathrm{Cr}-\mathrm{Mo}$ alloy after being located in quasi-biological environments using XPS, Appl Surf Sci, Vol.183,pp. 68-75,2001. 